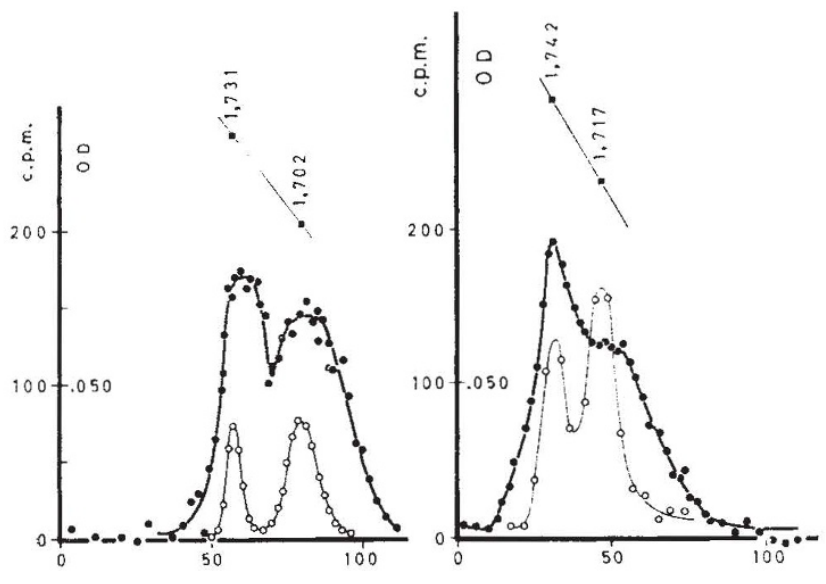

$a$

$b$ Fig. 4. CsCl density gradient centrifugation of DNA isolated from roots
of barley seedlings incubated with $M$. lysodeikticus DNA for $12 \mathrm{~h}$. with water for $72 \mathrm{~h}$ and with ${ }^{3} \mathrm{H}$-thymidine for $3 \mathrm{~h}$. Molecules of density 1.712 $\mathrm{g} / \mathrm{cm}^{3}$ (compare Fig. $2 b$ ) were ultrasonicated and analysed in neutral a) or in alkaline (b) CsCl gradient. Barley DNA and double stranded M. lysodeikticus DNA were used as density markers. activity; O-O, nltraviolet absorption. Abscissa, fraction No.

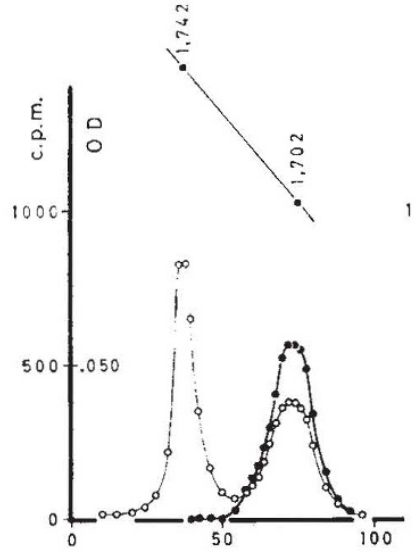

$a$

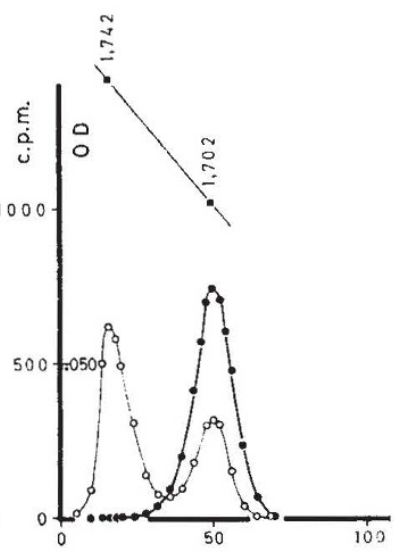

$b$ Fig. 5. CsCl density gradient centrifugation of DNA isolated from roots
of barley seedlings incubated with ultrasonicated $(a)$ or denatured $(b)$ of barley seedlings incubated with ultrasonicated $(a)$ or denatured $(b)$ M.lysodeikticus DNA for $12 \mathrm{~h}$, with water for $12 \mathrm{~h}$ and with ${ }^{3} \mathrm{H}$-thymidine for $3 \mathrm{~h}$. Denatured $M$. lysodeikticus DNA was used as a density
marker. Ahscissa, fraction No.

presumably result from the binding or integration of the foreign macromolecule to (or in) the endogenous one.

No replication of this type of molecule (labelling with tritium at a density of $1.712 \mathrm{~g} / \mathrm{cm}^{3}$ ) can be observed until some time after the initial "binding" of the ${ }^{32} \mathrm{P}-\mathrm{DNA}$.

This finding is very surprising. Among other possible hypotheses, it is tempting to suggest that the newly labelled molecules correspond to the stimulation of preexisting autoduplicating structures (for example, virus, PPLO, bacteria and subcollular organites) activated in an unknown way by the foreign DNA. The crucial argument against this hypothesis lies, however, in the observation that, after ultrasonication, two distinct peaks of radioactivity are obtained. In the case of an autoduplicating particle, only one broad peak, corresponding to the density of the intermediary $\mathrm{DNA}^{18}$, should be observed.

Because the genetic approach to this problem is a very difficult one, we have to rely for our interpretation on biochemical data. We can get no help from pre-existing genetic considerations, which was possible in the case of bacteriophage lambda ${ }^{13,14,19}$. On the other hand, the possibility of a foreign bacterial DNA attaching to the DNA of a higher organism raises many questions which are difficult to answer in the light of our present knowledge of plant chromosomes. We cannot, for example, suggest any precise mechanism for such an attachment. We can postulate, however, that such a mechanism should involve the pairing of small homologous regions of both DNAs (Volkin has recently discussed the biochemical grounds of the recombination phenomenon $\left.{ }^{20}\right)$.

It should, however, be emphasized that the results of the ultrasonication experiments suggest the attachment of a large piece of the foreign DNA to the endogenous DNA, for it is unlikely that, after ultrasonication, two clear-cut DNA species would be obtained if small parts of $M$. lysodeikticus DNA were integrated into the endogenous double strands ${ }^{15}$.

We thank Professors M. Errera, J. Brachet and H. Chantrenne for help and advice. This work was supported by a Euratom-CEN contract and by grants from the Fonds de la Recherche Scientifique Fondamentale Collective.

L. LedovX

Section de Biochimie Cellulaire,

R. HUART

Département de Radiobiologie,

Centre d'Etude de l'Energie Nucléaire,

Mol, Belgium.

Received April 18, 1968.

${ }^{t}$ Ledoux, L., and Huart, R., Arch. Intern. Physiol. Biochim., 69, 598 (1961).

2 Ledoux, L., AIEA Symp. on Biologicai Effects of Ionizing Radiation at the Molecular Level, 175 (1962).

${ }^{3}$ Ledoux, L., and Huart, R., Arch. Intern. Physiol. Biochem., '71, 822 (1963).

${ }^{4}$ Ledoux. L., Huart, R., and Baeyens, W., Arch. Intern. Physiol. Biochem., 73,563 (1965).

${ }^{5}$ Ledoux, L.. in Progress in Nucleic Acid Research and Molecular Biology (edit, by Davidson, J. in Nucleic Acid Research and Molecular Biolog.

'Ledoux, L., and Huart, R., Arch. Intern. Physiol. Biochem., 73, 873 (1965).

' Ledoux, L., and Huart. R. Arch. Intern. Physiol. Biochem., 74, 927 (1966).

${ }^{8}$ Ledoux, L., and Huart, R., Biochim. Biophys. Acta, 134, 209 (1967).

- Ledoux, L., La Pénétration et le Sort des Acides Désoxyribonucléiques dans les Celluies Vivantes (Vaillant Carmanne, 1967).

${ }^{10}$ Gautheret, R. J.. La Culture des Tissus Végétaux (Masson, 1959).

${ }^{11}$ Marmur, J., J. Mol. Biol., 3, 208 (1960).

12 Meselson, M., Stahl, F. W., and Vinograd, J., Proc. US Nat. Acad. Sci., 43 $581(1957)$.

${ }^{13}$ Meselson, M., and Weigle, H., Proc. US Nat. Acad. Sci., 47, 857 (1961).

${ }^{14}$ Kellenberger, M., Zichichi, M. L., and Weigle, H., Proc. US Nat. Acad. Sci., 47, 869 (1961).

13 Oppenheim, A. B., and Riley, M., J. Mol. Biol., 20, 331 (1966).

${ }^{16}$ Eigner, J., and Doty, P., J. Mol. Biol., 12, 549 (1965).

${ }^{17}$ Courts, W. B., and Flamm, W. G., Biochim. Biophys, Acta, 114, 628 (1966).

${ }^{18}$ Sueoka, N., Proc. US Nat. Acad. Sei., 45, 1480 (1959).

${ }^{19}$ Campbell, A., Advances in Genetics, 11, 101 (1962).

${ }^{20}$ Volkin, E., in Progress in Nucleic Acid Research and Molecular Biology (edit. by Davidson, J. N., and Cohn, W.), 4,51 (Acadenic Press, 1965).

\section{Effects of Anti-spleen Serum on Skin Allograft Survival and Blood Lymphocyte Reactivity in the Chicken}

IT has long been known ${ }^{1,2}$ that immunizing an animal with heterologous lymphoid tissue produces a serum which has a marked anti-lymphocytic effect in the species donating the lymphoid tissue. The wider significance of this finding was realized only recently, after injection of such anti-lymphocytic serum (ALS) had been shown ${ }^{3,4}$ to prolong greatly the survival of allografts. Although the potent immunosuppressive effect of ALS is now well established, elucidation of its mode of action is proving more difficult ${ }^{5-7}$.

It seemed that an investigation of the actions of antichicken ALS in skin-grafted chicks could be particularly useful, for there was an opportunity to alter selectively the immunological capacity of the chick recipients by tech. niques such as bursectomy ${ }^{8-10}$. A further consideration was the fact that the immunological reactivity of circu- 


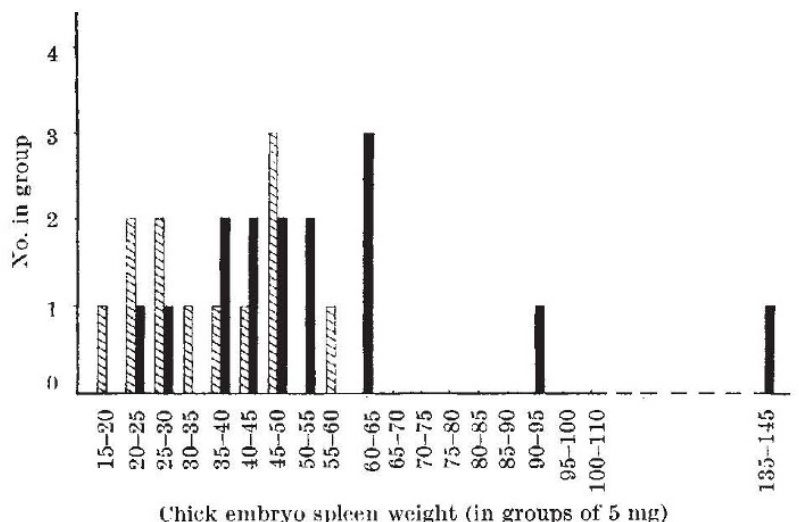

('hick embryo spleen weight (in groups of $5 \mathrm{mg}$ ) Fig. 1. Lffect of repeated injections of anti-chicken spleen serum on the competence of chick blood to produce GVH reaction (splenomegaly) in chick embryos. Solid columns represent pooled spleen weights from embryos injected with blood from three serum-treated chicks bearing weights from cmbryos in jected with blood from three saline-treated conweights from embryos injected with blood from three saline-treated conat 4 weeks old after twenty serum injections; $0.1 \mathrm{ml}$. was injected into 13 day old host embryos and spleen weight was determined 6 days later.

lating cells can be tested dircetly in the graft versus host (GVH) reaction which chicken blood produces in the chick embryo ${ }^{11}$.

Anti-chicken ALS was prepared by immunizing pairs of Porton eoloured rabbits by repeated intraperitoneal injection of White Leghorn (WL) hen spleen colls. In the first experiment, scrum from one pair of rabbits was injected shortly after 1 week old chicks had been grafted ${ }^{12}$ with allogeneic WL hen skin removed from the leg. The injections were continued daily until graft rejection occurred or until the experiment terminated. A daily intraperitoncal dose of $0.25 \mathrm{ml}$. of serum was used so that the group of nine chicks could be treated for up to 3 weeks. The ehicks did not appear to suffer any illeffects with repeated injections.

After a series of twenty daily injections, all the grafts macroscopically appeared healthy. One day after cessation of the injections, bood was withdrawn from the wing vein of some chicks and injected into chick embryos to see if it contained cells competent to produce $\mathrm{C} \mathrm{VHH}$ reaction. The three samples of blood from serum-treated chicks produced splenomegaly in recipient WL embryos equal to or greater than that observed with blood from three of the ten controls, which had already rejected their allografts (Fig. I). The degree and pattern of the splenomegaly were essentially similar when blood from the same animals was re-tested 6 days after the injections had been stopped.

The first test injection of blond from serum-treated chicks produced changes in the recipient spleens similar to those observed with blood from control chicks. Macroscopically, the spleen surfaces were irregular and studded with many superficial and discrete nodules. Histologically, these nodules were large focal patches of reticulum colls and such reticulum cell foci have been described ${ }^{13,14}$ as being characteristic of the splenomegaly in the $\mathrm{GVH}$ reaction in the ehick embryo. Many of the reticulum coll foci had necrotic centres surrounded by giant cells typical of the splenic changes in GVH reactions in donor host combinations with differences at the $B$ locus which largely controls histocompatibility in the chicken. Blood taken from chicks treated with scrum therofore remained capable of producing splenomegaly indistinguishable from that in the GVH reaction, although there was no visible homograft reaction against the skin allograft.

These results suggest that a population of circulating lymphocytes was present after serum treatment, and that these lymphocytes, though able to respond to WL antigens in the chick embryo, did not respond or were unable to respond in vivo to similar foreign WL antigens in the allograft. This is not in accord with results in mice $e^{7,15,16}$ where only a few injections of ALS were needed to inhibit the GVH activity of lymph node and spleen eells.

The lack of inhibition of chicken peripheral lymphocytes may well be a consequence of a species difference in the cellular mechanisms involved in the GVH reaction. A similar difference between monkeys and mice has also been described ${ }^{15}$. Treatment of monkeys with ALS for up to 5 woeks, using doses known to suppress effectively skin allograft rejection, failed to modify the acute secondary disease in the irradiated recipients of the bone marrow from ALS-treated animals.

It could be concluded therefore that multiple injection of ALS in chicks did not result in inactivation or "blindfolding" of peripheral lymphncytes by coating of receptor sites with xenogeneic antibody, ${ }^{5,6}$. (On the other hand, experiments ${ }^{7}$ with ALS in mice suggest the alternative explanation that no inhibition was observed becanse chicken blood was tested too late after injection of ALS to detect cells still retaining a coating of antibody.

In the second experiment, in which twelve chicks were bursectomized when 1 day old before allografting and treatment with ALS, blood was tested for immunological competence after only five injections. Four blood samples were testod and there were apparently sufficient reactive lymphocytes present to produce a detectable GVH reaction; fourteen out of thirty-five spleens were in the 20-35 mg weight range while the rest fell within normal limits $(15-20 \mathrm{mg})$. Blood samples from the same four chicks tested after a furthor week of ALS injections, and again at 7 weeks of age, seemed, however, to be no more effective, only six out of twenty-two and thirteen out of thirty-five spleens, respectively, weighed $20-35 \mathrm{mg}$.

Bursectomized chicks were much less tolerant of repeated injections of serum from the second pair of immunized rabbits; four out of twelve chicks died after receiving nine to eleven injections. Varying degrees of graft survival were observed in the bursectomized chicks which survived. Two showed no prolongation and two slight prolongation (17-18 days). In another two chicks, parts of the graft survived for 5 weeks, while in the remaining two chicks the whole graft remained healthy while injections were continued, as was the case with four sham-operated controls with intact bursa. After injections had been stopped, gradual shrinkage of the graft with apparent replacement by host scar tissue occurred over 9 days in both bursectomized and control chicks. Bursectomy therefore did not influence to any extent the pattern of graft survival during ALS treatment nor graft deterioration subsequently.

These fow results do not suggest that antibody production by the host against ALS, or processes such as sterile activation play important parts in the mechanism of ALS action in the chicken.

In conclusion, the observation that immunologically active cells persist in the peripheral circulation during ALS treatment and that such cells are also detectable after bursectomy suggest that ALS might prevent allograft rejection by effects on the graft ${ }^{17}$. If, however, there are two or more populations of lymphocytes in the fowl ${ }^{18}$ then ALS could have conceivably inactivated a population of cells responsible for allograft rejection, but left intact a sub-population concerned with the GVH reaction.

I thank Dr J. J. T. Owen for a useful discussion and assistance in interpreting the histolngical findings.

\section{F. TCCKER}

Cancer Chemothcrapy Unit,

Imperial Cancer Research Fund, London.

Received March 29; revised May 2, 1968

${ }^{1}$ Chew, W. B., and Tawrence, J. S., J. Immunol., 52, 101 (1937).

${ }^{2}$ Cruickshank, A. H., Brit. J. Exp. Pathol.,22, 126 (1941).

${ }^{3}$ Woodruff, M. F. A., and Anderson, N. A.. Nature, 200, 702 (1963). 
4 Woodruff, M. F. A., and Anderson, N. A., Ann. NY Acad. Sci., 120, 119 (1964).

${ }_{5}^{5}$ Levey, R. H., and Medawar, P. B., Ann. NY Acad. Sci.,129, 164 (1966). 'Levey, R. H., and Medawar, P. B., Proc. CS Nat. Acad. Sci., 56, 1130
$(1966)$.

'Brent, L., Courtenay, T., and Gowland, G., Nature, 215, 1461 (1967).

8 Glick, B., Chang, T. S., and Jaap, R. A., Poultry Sci, 35, 224 (1956).

${ }^{\circ}$ Mueller, A. P., Wolfe, H. R., and Meyer, R. K., J. Immunol., 85, 172 (1960).

Mueller, A. P., Wolfe, H. R., Meyer, R. K., and Aspinall, R. L., J. Immunol. . 88, $354(1962)$.

${ }^{11}$ Simonsen, M., Brit. Med. Bull.,21, 129 (1965). ${ }^{12}$ Polley, C. R., Grosse, A. E., and Craig, J. V., Transplant Bull., 7, 25

${ }^{13}$ Biggs, P. M., and Payne, L. N., Immunology, 4, 24 (1961).

${ }^{14}$ Biggs, P. M., and Payne, L. N., Immunology, 4, 38 (1961).

${ }^{15}$ van Bekkum, D. W. Ledney, G. D., Balner, H., van Putten, L. M., and de Vries, M. J., Ciba Foundation Study Group on Antilymphocytic Serum (edit. by Wolstenholme, G. E. W., and $O^{\prime}$ Connor, M.), 97 (J. and A. Churchill, London, 1967)

${ }^{16}$ Boak, J. L., Fox, M., and Wilson, R. F., Lancet, i, 750 (1967).

${ }^{12}$ Gutimann, R. D., Carpenter, C. B., Lindquist, R. R., and Merrill, J. P., Lincet, i, 248 (1967).

${ }^{18}$ Szenberg, A., and Shortman, K., Amn. NY Acad. Sci.,129, 310 (1966),

\section{Effect of Serum from Tolerant Mice on Immunity and Tolerance to a Bacterial Antigen}

THE mechanism of immunological tolerance is still poorly understood. Numerous model systems have been used in attempts to resolve some of the important questions concerning the fundamental role of both antigen and antibody in the establishment and maintenance of immunological tolerance to various antigens, in a variety of conditions in mammalian or avian species ${ }^{1-3}$. It has been observed recently that establishment of immunological tolerance to certain antigens, such as serum proteins, foreign erythrocytes or bacterial extracts, can be prevented by specific antiserum ${ }^{4-9}$. The suppressive effect of antibody on the induction of tolerance seems to be similar in many respects to the effect of specific antiserum on antibody formation.

A number of investigators have found that serum antibody is important in the regulation of antibody at the cellular as well as the humoral level ${ }^{10-13}$. A relationship between serum antibody and induction, maintenance or termination of immunological tolerance is not yet clear.

Previous studies in our laboratory have shown that passive administration of antiserum to Shigella antigens suppresses induction of specific tolerance in newborn mice ${ }^{4,14}$. The time of serum inoculation in relation to antigen injection was important because tolerance could be blocked only when antibody was administered simultaneously or within 2 days after antigen had been given. Further studies indicated that injection of antiserum later in life, when tolerance was already established, had little or no demonstrable effect on maintenance of unresponsiveness. Several other investigators have observed that tolerance to protein antigens can be blocked either in neonatal or adult mice by simultaneous administration of antiserum to the specific antigen. Passive transfer of hyperimmune homologous or heterologous serum following establishment of tolerance has usually had little effect on unresponsiveness ${ }^{1,5,15}$.

The biological effect of de novo antibody synthesis in animals "escaping" from tolerance, especially as related to maintenance of tolerance after additional injections of antigen, is not known. The relation of antibody activity in partially tolerant animals, as well as in immune animals, to establishment or maintenance of tolerance is also not clear. The experiments described here are concerned with effects of serum antibody obtained from mice "escaping" from immunological tolerance to Shigella antigen on induction of either immunity or tolerance in other recipient animals. The results obtained suggest that, despite similar titres, there may be both quantitative and qualitative differences in antibody activity to
Shigella antigen in sera of mice recovering from tolerance, as compared with antibody in sera of actively immunized animals.

For these experiments newborn NIH albino A mice were inoculated with $20 \mu \mathrm{g}$ of Shigella soluble antigen (SSA), as described previously, to induce specific immunological tolerance ${ }^{4,16}$. Such mice were unresponsive to challenge immunization with a concentration of Shigella antigen capable of inducing relatively high agglutinin titres in control mice. As Table 1 shows, mice injected with SSA as neonates rarely had titres greater than

Table 1. EFFECT OF SERA FROM TOLERANT, IMMUNE OR NORMAL MICE ON ESTABLISHMENT OF TOLERANCE OR INDCCTION OF AGGLUTININ FORMATION IN EITHER NEONATAL OR ADULT MICE

Peak agglutinin titres after challenge immunization*

\begin{tabular}{|c|c|c|c|c|c|}
\hline \multirow{2}{*}{$\begin{array}{l}\text { Mouse serum } \\
\text { injected }\end{array}$} & & ant mic & te in & & Normal adult \\
\hline & 3 & 5 & 8 & 10 & mice \\
\hline None (saline) & $1: 25$ & $1: 29$ & $1: 15$ & $1: 43$ & $1: 405$ \\
\hline Normal & $1: 18$ & $1: 32$ & $1: 27$ & $1: 48$ & $1: 460$ \\
\hline Early tolerant\$ & $1: 30$ & $1: 23$ & $1: 16$ & 40 & $1: 415$ \\
\hline Late tolerantll & $1: 14$ & $1: 32$ & $1: 22$ & & $1: 493$ \\
\hline Early immune I & $1: 138$ & $1: 343$ & $1: \overline{3} 92$ & $1: 316$ & $1: 64$ \\
\hline Hyperimmune** & $1: 248$ & $1: 365$ & $1: 330$ & $1: 410$ & $1: 10$ \\
\hline
\end{tabular}

* Mean titres of five or more mice per group per day were tested.

$\dagger$ Mice injected at birth with SSA and serum indicated; challenged with $\mathrm{SA}$ at age indicated and serum titres determined 7-15 days later.

$\ddagger$ Groups of $7-10$ week old untreated adult mice injected with serum indicated, followed by challenge immunization with SSA; serum titres determined $7-15$ days later.

\$Sera obtained 5-7 days after challenge immunization of $2-3$ month old "early" tolerant mice; agglutinin titre $=1: 32$.

1] Sera obtained 5-7 days after challenge immunization of 5-8 month old late" tolerant mice; agglutinin titre $=1: 256$

20 Sera obtained 1 week after primary injection of $5-7$ week old mice with $20 \mu \mathrm{g}$ of SSA; agglutinin titre $=1: 384$.

*

$1: 40$ when subsequently challenged with the same antigen. Control, non-tolerant animals responded with much higher agglutinin titres when challenged with Shigella antigen. Both groups of animals formed relatively similar amounts of circulating antibody to unrelated antigens such as sheep erythrocytes or bovine serum albumin (Table 2).

Table 2. ANTIBODY TITRES OF TOLERANT AND CONTROL MICE TREATED WITH SERA FROM TOLERANT OR IMMUNE MICE AND INJECTED WITH EITHER SHIGELLA
OR CONTROL ANTIGENS

\begin{tabular}{clccc}
\multirow{2}{*}{ Mouse group } & \multicolumn{1}{c}{$\begin{array}{c}\text { Serum } \\
\text { injected }\end{array}$} & Antibody titres after immunization \\
\cline { 2 - 5 } Tolerant* & Non & S-RBC & BSA \\
& None & $1: 31$ & $1: 712$ & $1: 480$ \\
& Late tolerant $\dagger$ & $1: 23$ & $1: 824$ & $1: 554$ \\
Normal control & Nyperimmune $\ddagger$ & $1: 480$ & $1: 768$ & $1: 425$ \\
& Late & $1: 415$ & $1: 928$ & $1: 470$ \\
& Hyperimmune $\ddagger$ & $1: 392$ & $1: 845$ & $1: 515$ \\
& $1: 12$ & $1: 910$ & $1: 538$
\end{tabular}

* Mice injected at birth with SSA; treated when 4-6 weeks old.

+ Sera obtained $5-7$ days after challenge immunization of $5-8$ month old
S † Sera obtained $5-7$ days after challe
tolerant mice; agglutinin titre $=1: 256$ t Sera obtained $5-7$ days after fourth monthly injection of normal adult
micc with $20 \mu$ of SSA; agglutinin titre $=1: 10,240$.

micc with $20 \mu \mathrm{g}$ of SSA; agglutinin titre $=1: 10,240$.
Groups of five to eight mice each immunized with either $20 \mu \mathrm{g}$ of SSA, Groups of five to eight mice each immunized with either $20 \mu \mathrm{g}$ of SSA,
$2 \times 10^{8}$ sheep erythrocytes, or $5 \mathrm{mg}$ of bovine serum albumin (BSA) Freund's adjuvant; antibody titres determined 8-15 days later.

Sera were pooled from mice of various ages after neonatal establishment of tolerance for passive transfer into other mice. Sera from tolerant mice less than 3 months old rarely had significant agglutinin titres. Also, there was no detectable Shigella antigen in these sera, as shown by several serological inhibition procedures. Serum specimens were also obtained from older mice, usually 5 to 8 months old, emerging spontaneously from the tolerant state. Such mice often had specific agglutinins to Shigella, usually with titres of $1: 100-1: 200$ or more, within 1-2 weeks after challenge immunization with SSA. Control negative sera were prepared from normal, noninjected mice, while control positive sera were obtained from mice which had received three or more monthly injections of SSA. Such sera usually had titres of $1: 5,120$ or more. For some experiments, gamma globulin fractions derived from these pooled sera were prepared by precipitation with 30 per cent ammonium sulphate. Results obtained either with the gamma globulin or the whole sera were equivalent. 